DOI: https://doi.org/10.34069/AI/2021.48.12.22 How to Cite:

Horbolis, L., Ishchenko, O., Novykov, A., Marieiev, D., \& Hrychanyk, N. (2021). The Cinemapoetics of the modern Ukrainian novel: Myroslav Dochynets' creative works. Amazonia Investiga, 10(48), 209-217. https://doi.org/10.34069/AI/2021.48.12.22

\title{
The Cinemapoetics of the modern Ukrainian novel: Myroslav Dochynets' creative works
}

\section{Кінопоетика сучасного українського роману: творчість Мирослава Дочинця}

Received: November 22, 2021

Accepted: December 28, 2021

\author{
Written by: \\ Larysa Horbolis ${ }^{89}$ \\ https://orcid.org/0000-0003-4775-622X \\ Olena Ishchenko" \\ https://orcid.org/0000-0001-9274-8566 \\ Anatoliy Novykov ${ }^{11}$ \\ https://orcid.org/0000-0001-5158-960X \\ Dmytro Marieiev ${ }^{22}$ \\ https://orcid.org/0000-0002-6282-8052 \\ Nataliya Hrychanyk ${ }^{93}$ \\ https://orcid.org/0000-0002-0616-6832
}

\begin{abstract}
The article presents a review of the Ukrainian literary critics' works on the relationship between literature and cinema, the relevance and effectiveness of the practice of involving cinematic resources in the literary works of Ukrainian writers of the 20th - early 21st centuries. On the material of the novels "Centenarian. Confession on the Pass of the Spirit", "Svitovan. Studies under the Tent of the Skies", "Well-Digger. Diary of the Richest Resident of Mukachevo Dominion", "Highlander. Waters of Our Lord's Riverbeds", "Maftei. Book Written with a Dry Pen" by the contemporary Ukrainian writer M. Dochynets traces the problem of inter-artistic interaction of literature and cinema. The purpose of the research is to single out and analyze film frame, montage, shot, perspective, rhythm as integral elements of the cinematic poetics of M. Dochynets 'prose, which are used in the text to reveal the artistic, aesthetic, philosophical and creative principles of the writer. The study used general scientific (analysis, synthesis, comparison) and literary methods: the systematic approach, hermeneutic method, principles of
\end{abstract}

\footnotetext{
${ }^{89}$ Doctor in Philology, Professor at the Department of Ukrainian Language and Literature, Sumy State Pedagogical University named after A. S. Makarenko, Sumy, Ukraine.

${ }^{90} \mathrm{PhD}$ in Philology, Assistant Lecturer at the Department of Journalism and Philology, Sumy State University, Sumy, Ukraine.

${ }^{91}$ Doctor in Philology, Professor, Head of the Department of Ukrainian Language, Literature and Methods of Teaching, Oleksandr Dovzhenko Hlukhiv National Pedagogical University, Hlukhiv, Ukraine.

${ }^{92} \mathrm{PhD}$ in Philology, Associate Professor at the Department of Ukrainian Language, Literature and Methods of Teaching, Oleksandr Dovzhenko Hlukhiv National Pedagogical University, Hlukhiv, Ukraine.

${ }^{93} \mathrm{PhD}$ in Pedagogy, Seniour Lecture at the Department of Ukrainian Language, Literature and Methods of Teaching, Oleksandr Dovzhenko Hlukhiv National Pedagogical University, Hlukhiv, Ukraine.
} 
narratology, intermedia approach. Appealing to the works of $\mathrm{O}$. Chicherin, S. Eisenstein, Yu. Lotman, M. Romm, A. Tarkovsky, etc., the peculiarities of the use of film poetics in the writer's novels are analyzed. It was found out that in prose by M. Dochynets montage, film frame, shot, rhythm, foreshortening perform intonation-expressive, plot-compositional and characterological functions.

Keywords: literature, cinemapoetics, cinemapoetics elements, montage, film frame.

\section{Introduction}

Interartistic relationship between Ukrainian literature and cinema became noticeably more active at the beginning of the 21st century thanks to the activities of Mykhailo Semenko, D. Buzko, Mykhailo Maisky, Oles Dosvitny, Y. Yanovsky, M. Bazhan, Geo Shkurupiy, G. Epik, Dmytro Falkivsky, and others, who realized themselves as screenwriters, teachers of film theory, critics, editors, etc. The work of O. Dovzhenko, who in 20-30 years successfully mastered the genre of film storytelling, Development of the Ukrainian literary process of the late 20 th - early 21 st centuries takes place in a synthesis of arts, which requires writers to appeal to theater, choreography, music, painting and especially cinema, which is now gaining a dominant position.

Among a number of modern Ukrainian prose writers, Myroslav Dochynets stands out for his original worldview, philosophical thinking and refined artistic taste. "Centenarian. Confession on the Pass of the Spirit", "Svitovan. Studies under the Tent of the Skies", "Well-Digger. Diary of the Richest Resident of Mukachevo Dominion", "Highlander. Waters of Our Lord's Riverbeds", "Maftei. Book Written with a Dry Pen" ${ }^{94}$ created a convincing image of a wise elderly man with his own philosophical system with the help of both literary pictorial and expressive means and cinematographic ones. The prose writer emphasizes the kinship of cinema and literature, as they operate with similar pictorial and expressive means, capable of "one stroke, one fragment, one scene" (Dochynets, 2013c, 10-11) to create an artistic image and saturate it with subtext. $\begin{array}{lcr}\text { герменевтичний } & \text { метод, } & \text { принципи } \\ \text { наратології, } & \text { теоретичні }\end{array}$

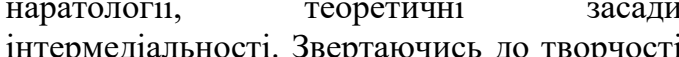
О. Чичеріна, С. Ейзенштейна, Ю. Лотмана, M. Ромма, А. Тарковського та ін., проаналізовано особливості використання кінопоетики в романах письменника. У підсумках наголошено, що в прозі М. Дочинця монтаж, кадр фільму, план, ритм, ракурс виконують інтонаційно-виразну, сюжетно-композиційну та характерологічну функції.

Ключові слова: література, кінопоетика, засоби кінопоетики, монтаж, кадр.

In the study of the prose by M. Dochynets, we use the definition of S. Ezenstein (Ezenstein, 1968), who understood film poetics as a system of pictorial and expressive means of cinema involved in a literary work. The article identifies and analyzes the following elements of the cinemapoetics of the novels "Centenarian", "Svitovan", "Highlander", "Well-Digger", "Maftei" film frame, montage, shot, perspective, rhythm as a means of expressing artistic, aesthetic, philosophical and creative principles of writer.

\section{Theoretical Framework}

In the Ukrainian literary criticism of the early twentieth century, the study of the artistic reproduction of cinematic means in the modern Ukrainian novel became relevant. Known investigations O. Braiko, L. Pechersky, Y. Sokolovskaya and others.

Nowadays, the Ukrainian literary discourse is dominated by the idea of active mutual enrichment of both arts in the process of interaction: the cinematography of literature created favorable conditions for the development of cinema, and later began to borrow its means. In understanding the intermedia interaction of literature and cinema, it is appropriate to turn to Lotman's idea of the universality of culture, its ability to combine codes of different arts in the structure of a work of art (Lotman, 1992, p. 143). The researcher is convinced that inter-artistic interaction is a powerful meaning-making factor. The desire for generalizations can be explained by the specifics of the human psyche, which aims to "conceptualize and categorize the world,

\footnotetext{
${ }^{94}$ Then we use the abbreviated titles of the novels: "Centenarian", "Svitovan", "Highlander", "Well-Digger", "Maftei”.
} 


\section{AMAZOND瓜}

which do not depend on the criteria of authorship, time of creation, sociolinguistic and ethnocultural variables" (Kravchenko, 2020, p. 156).

Taking into account the experience of predecessors, modern Ukrainian writers seek to realize themselves in the field of cinema. For example, M. and S. Dyachenko, B. Zholdak, O. Ilchenko, A. Kurkov, Y. Pokalchuk, V. Portyak, V. Potrukh and others have combined literary activity with cinema, theater and television (mostly by writing scripts or acting as a director). Also there are some successful film projects that have found fans among the audience; they are screened re-reading of literary works of Ukrainian classics I. Franko, I. Nechuy-Levytsky (with new plot lines, new characters, etc.) (Filatov, 2012).

Particular attention should be paid to the works of modern writers with a widely represented combination of expressive possibilities of words and cinematic means, due to which in literary works there is 1) replacement of one code with another (full or partial at the level of content or form); 2) mixing verbal and cinematic elements; 3 ) the kinship of the word and the film that creates the code, which has the characteristics of both the first and the second (Dotsenko, 2015, p. 54).

\section{Methodology}

The set of general scientific and special literary methods is used to perform the achieve the objectives of the research. Working on the theoretical material on the topic through analysis, synthesis and comparison, we found that in modern literary-critical discourse there is increased attention to the creative work of M. Dochynets. It was found that the studies of literary critics are devoted mainly to general issues of studying the writer's works with emphasis on understanding their artistic value and artistic features of individual novels or samples of short prose, genre-style nature, specifics of artistic modeling of the character etc. With the help of general scientific methods it was found out that the film poetics of the prose by M. Dochynets was not the object of special study.

A detailed study of the cinemapoetics of the M. Dochynets prose it would not be possible without the use of special literary methods. The systematic approach contributed to the study of the cinemapoetics of the writer's novels as an unity of system-structural levels (film frame, montage, shot, perspective, rhythm).
Hermeneutic method, which involves understanding the literary text as a structure that has a semantic unity, endowed with a generative function of meaning, contributed to a comprehensive interpretation of the elements of the cinemapoetics, influencing the modeling of the characters' concept, issues, ideological and thematic load of novels. Through the principles has determined the specifics of the teaching forms of novels, which are realized with the help of the cinemapoetics. The method helped to determine their significance for the interpretation of the original concept of the character, the interpretation of the ideological and thematic section of prose, the relationship between the author and the recipient. The intermedia approach is used to establish the relationship between literature and cinema in the M. Dochynets prose.

\section{Results and Discussion}

The polysynthetic genre nature of the novels "Centenarian", "Svitovan", "Highlander", "Well-Digger", "Maftei” by M. Dochynets skillfully combines the features of the novelparable (philosophical, moral and ethical load, dichotomy, metaphorical, laconicism, appropriate literary type - the bearer of the idea), a biographical novel (artistically modeled biography of a person endowed with virtues), a novel-confession (first-person narrative, the character's story about the most secret depths of the soul in an attempt to comprehend the changes that occurred over time in the character's mind), diary novel memories of the character in the form of diary entries, which deal with events that played a crucial role in shaping worldviews and moral priorities), which determines the construction of the narrative in the form of memory, confession, sleep, dialogues with students and monologues, etc. Artistically reproducing the peculiarities of the psyche and ethnopsychological dominants of a wise old man who seeks to pass on his life experience and knowledge of the world acquired over a long life, the writer identifies the memory of the protagonists as an important visual and plotcreating factor. Thus, the process of memorizing and updating information involves both visual images and their verbal interpretation. The implementation of mental operations in the human mind occurs in the form of frames, which through editing are combined into moving images. This feature of the human psyche was borrowed by literature and cinema to create artistic reality (Lotman, 1998, p. 12). M. Romm's opinion is correct, who, agreeing with S. Eisenstein, remarked: "Editing thinking is the 
basis of creativity" (Romm, 1964, p. 56). Other categories of film poetics are inextricably linked with the film frame and montage - plan, perspective, rhythm, etc.

The genre paradigm and ideological and thematic section of the novels by Myroslav Dochynets determined the dominance of I-narration aimed at the psychological self-disclosure of the protagonist in the form of a "stream of consciousness": the character's memories are combined with reflections purpose of man, the importance of family and folk traditions, etc.). This method of narrative strategy in the novels "Centenarian", "Svitovan", "Highlander", "Well-Digger", "Maftei" associatively combines several space-time planes: chronological-linearabout the life and work of the character in reality and retrospective, which gradually presents the process of formation of life philosophy and actualization of ethnomental constants. Thus, in the prose by $\mathrm{M}$. Dochynets there is an alternation of sequential and parallel retrospective montage. The plot lines are also accompanied by a story about the life of the protagonists, who were used to represent Andriy Voron (Centenarian/Svitovan), Highlander, WellDigger, Maftei as imitators of national and family traditions, guardians of ancestral memory.

Each film frame in the novels by M. Dochynets is not just a photographic reproduction of a certain moment in the life of the characters, but saturated with the help of Chicherin's "montage projection" with a deep image that creates the illusion of movement aimed at revealing their inner world, ethnopsychological features, means of tracking the formation of life philosophy, etc. The writer focuses on the emotionally tense moments that have the maximum impact on the consciousness of the recipient. Thus, in the episode of Andriy Voron's escape from Hungarian captivity, M. Dochynets uses the pictorial possibilities of quick montage to visualize a state of despair and fear, which intensifies with each new shot: "One salvation has spread - the forest. <...> What will I do in the thicket myself - that's what I was afraid to think. The virgin forests were deaf and dark, and the eyes were eaten away by gray mountain ash. Depressed compressed silence and closed space. $<\ldots>$ I ran away from fear to fear, from yesterday - into obscurity. I was a stranger here, and everything was alien and wild to me. The early evening twilight was as oppressive as the age of agreement" (Dochynets, 2013a, p. 11). Wordsmarkers compressed silence, isolation, fear, stranger, wild, obscurity, agreement express feelings of hopelessness. The emotional state of the character is projected on the perception of wildlife, which appears for the character as a hostile environment. The image of the forest is created with the help of the thicket, wilderness, which reveal the character's fear of the unknown. Describing the environment, the character uses effective cinematic means - color (dark, gray, mountain ash) and sound accents (deaf, silent), which enhance the vision of despair of the character. Despite the fact that the hero was born and raised in the Carpathian Mountains, this was the first experience of interaction directly with wildlife, which is perceived as an alien, hostile space, as Andriy Voron in this episode is just beginning a long journey of learning nature and understanding its laws.

In the prose by $M$. Dochynets, in addition to quick montage, the technique of slow montage is actively used, which promotes the interpretation of "the silenced meaning or dominant parts of the depicted, encouraging the recipient to read thoughtfully" (Bulbachynska, 2019, p. 10). The combination of film frames in such episodes is carried out in order to have a psychological impact on the recipient. Thus, in the novel "Centenarian", the protagonist reports on the changes that took place in his worldview under the influence of forced solitude among the wildlife of the Carpathians: "In every manifestation, in every movement, in every change. <...> I learned to obey that world, to find my place in it. I approached the main thing - the need to serve, the ability to choose your business, start it and carry it to completion" (Dochynets, 2013a, 117). Slow montage reveals the key ideas of the character's life philosophy: 1) a person has unlimited potential on the path of selfimprovement; 2) everyone must find their "natural work" that will help to self-actualize through service to God and others; 3) man and nature must coexist in harmonious unity. As the writer's novels have a clear philosophical and didactic orientation, the episodes, which contain the character's thoughts and teachings, encourage intellectual dialogue and are aimed at motivating spiritual and physical selfimprovement.

In his novels, M. Dochynets actively uses the expressive possibilities of nonverbal elements of "sounding" verbal images, in particular, musical accompaniment characteristic of cinema. For example, the episode of the celebration of the temple holiday from the novel "Highlander" has a kind of two-level structure, which is built by combining the text of the work of art and the text of kolomyika (a variety of Ukrainian folk songs), performed to the sounds of musical instruments 


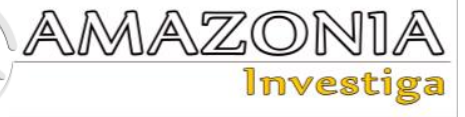

- violins, tambourines, cymbals. A young protagonist comes to the party to talk and dance with his chosen one. The importance of the moment for the hero is emphasized in the text with the help of quick editing and speeding up the rhythm of the story: "The lively melody lingered in the nailed grass, spread in the evening mist, rose up with the juices of the spruce trees. The trunks resonantly hummed like tight strings. <...> They shook their heads, intertwined their" (Dochynets, 2013a, p. 30). Musical framing reveals the emotional state, the specifics of the worldview and motivation of the character's behavior. In addition to the visual function, the musical accompaniment intensifies the microconflict of the work (aggravation of relations with the rival Sten) and performs the plot function (the main character and his chosen one openly express their feelings for the first time). In this fragment, nonverbal elements also specify the leading idea of the novel - a person at the genetic level inherits knowledge, skills and abilities from their ancestors, because it is an integral part of the Family (Highlander is able to subconsciously feel the rhythm of music and actualize dance experience).

An integral part of the cinemapoetics of M. Dochynets' prose is the rhythm, which together with the montage and the film frame determine the dynamics and plasticity of the work of art. A. Tarkovsky considered rhythm as a "full-fledged dominant", which "expresses the flow of time in the middle of the frame" (Tarkovsky, 1979, p. 88-90). M. Dochynets depicts the type of character for whom physical and mental activity is a necessary condition for self-actualization and self-knowledge. Numerous travels of the characters, their physical and psychological trials, meetings with extraordinary personalities contributed to the formation of an original philosophical system, for which the path of constant spiritual self-improvement and the search for mental balance are a priority. Within the chronological-linear narrative of the life and activity of the character in the reality for him, a slow pace of personnel change is used, the purpose of which is to emphasize the measured, steady pace of life of the characters. Each of the protagonists of the writer performs his daily "act of service": Centenarian - gains life experience and shares it with others, Well-Digger - acquires wealth and builds his hometown, Highlander saves his home from destruction by the elements, Maftei - treats girls and seeks out.

In the prose by $M$. Dochynets, rhythm also performs an important characterological function. The main characters are presented as an organic part of the environment, coexisting with it in a single rhythm. Nature is interpreted as a powerful factor of self-identification, as approaching it reveals the inner world of the heroes and determines their spiritual potential. In the novel "Centenarian", the protagonist Andriy Voron was forced to hide far from home, in the Black Forest, where he learned to survive in extreme conditions and managed to comprehend the structure of the Universe: "As long as I live and live among the living, I must obey the seventh law. For I am not taller than a tree, nor wiser than a bear, nor purer than a fish, nor more beautiful than a roedeer. I am only equal among equals, a small part of the living world, a drop of mystery, the result of the work of the Great Master" (Dochynets, 2013a, p. 65). The main characters of the writer's novels are convinced that the inner world of man (microcosm) is a reflection of the boundless world (macrocosm). Thus, their main purpose is to proclaim knowledge of the laws of nature and the organization of harmonious coexistence with it (echoes in the work of the writer of the idea of "three worlds" G. Skovoroda). Acquired life experience and knowledge of the environment, the skill of healing, they use to help other people (the idea of "nature work" by G. Skovoroda). Andriy Voron from the novel "Svitovan" is depicted at the beginning of the work as a physically and psychologically mature person. His follower journalist remarks that when he finds himself in a forest or meadow among tall grass, the mentor changes, and his sedentary activity changes: "A narrow river cracked its face, another here - moving, sharp, mountainous. She threw pearly foam through the jagged stones. The old man often stopped, picked up a mushroom invisible in the fern and threw it in his backpack. He leaned as if by accident, and over some grasses, plucked them. It turned out for him easily, hastily, well-filled way. His eyes really saw "something", instantly find the necessary from space, and his hands neatly took it out. In some ways, it resembled a bird that deftly extracts larvae from the bark" (Dochynets, 2014, p. 35). As we can see, M. Dochynets emphasizes the kinship of the character and nature with the help of personnel changes and the variability of the whole picture. Andriy Voron's activity reflects the fast rhythm of nature and is artistically realized with the help of such marker words as by accident, easily, hastily, instantly find, deftly. The writer skillfully combines and alternates concise descriptions of nature and the dynamics created in the frame through movement. 
Depicting the activities of the characters, M. Dochynets thoughtfully alternates the intense and slow rhythms of the story. For example, in the novel "Highlander" the protagonist is presented as a man who for many years was accustomed to transport goods from the shepherds to loggers' camp. The old man shares his usual daily activities with his horse, with which he has learned to coexist in one rhythm: "Di!" - He said to the horse. And he moved, guessing the road with his hooves. <...> But both the man and the horse knew, heard with their feet, walking in a continuous ascent, from mountain to mountain ... They understood each other in this road-work. Without words and unnecessary movements" (Dochynets, 2013b, p. 7). The usual leisurely rhythm of the character's life is changed by the element that destroys the house, takes the life of his wife and gradually washes away the shore with the "family nest". For Highlander, this becomes a difficult psychological test, because all his life he perceived River as a living being, a powerful helper and a faithful friend. The writer notes that, returning from the hospital, the protagonist begins to organize life "in a new way". His main purpose is to fight with River to preserve its space - this is his "nature work". Exercise helps to overcome psychological trauma. The Highlander gradually changes, failures only harden him and motivate him. Despite his respectable age, the character begins active activities: mowing the grass, tidying up the house, strengthening the shore, etc. In the episodes depicting the active physical activity of the character, an intensive alternation of shots is used, which enhances the dynamics: "The old man cut down an alder and leaned one end into a pine tree and the other into a larch tree. And began to thin the trunk with magnificent blows. Suddenly the core of the tree crackled like a broken spine. He quickly rushed to the alder support and hung on it. A mighty pillar in two human arms swayed in mortal contemplation and thundered down, piercing with noise of the air and tearing the sky with its branches. <...> The river howled with a painful surprise, and the cry died away in the abundant branches" (Dochynets, $2013 b$, p. 104-105). In this fragment, the dynamics is also achieved through the use of marker words that indicate the acceleration of the rhythm: suddenly, quickly rushed, swayed. The effect is enhanced by sound accents: crackled, thundered, piercing with noise, howled.

In novels by $\mathrm{M}$. Dochynets, the retrospective space-time plane is artistically reproduced with the help of both slow and intense alternation of frames. In episodes from the past, rhythm is presented as an element of "psychologically motivated montage of different fragments of the character's experience" (Braiko, 2017, p. 67) which is used to reveal the inner world of the character and reveal the changes in his mind. For example, in the novel "Centenarian", the intense rhythm of the protagonist's story about the events of the Battle of the Red Field for Carpathian Ukraine and the escape from captivity in March 1939 often changes slowly. Memoirs are presented from the point of view of a modern character - a wise old man, and therefore are supplemented by comments, philosophical maxims, instructions that slow down the rhythm of the story, associatively combined, form a "stream of consciousness". The main topics of reflection are the essence of man, his purpose in the world, the path of spiritual growth and bodily self-improvement (the process of "gathering the Spirit", "the Act of service"), emphasis on the meaning of gender, Christian precepts, folk traditions, national identity for modern man. Of particular importance for the figurative and ideological-thematic levels of prose by $M$. Dochynets is existential issues, in particular the understanding of the motive of freedom and loneliness. The defining feature of the original philosophy of the protagonists of M. Dochynets is the interpretation of loneliness not as a negative phenomenon (the ideas of A. Camus (1990), J.-P. Sartre (1948), etc.). Emphasizing the existential vector of presentation of the images of the main characters, the writer carefully selects the frames, presents them in a measured-slow rhythm, creates expansive visual visions to attract the recipient to the intellectual dialogue.

Since rhythmics, as we know, is built depending on "the degree of emphasis of each word, the strength of emphasis of keywords, the intonation of words in a sentence, sentences in a paragraph" (Chicherin, 1980, p. 214), M. Dochynets pays special attention to verbal and sound design works. For example, in the novel "Highlander" the creation of a general emotional tone occurs through the rhythmic separation of individual words (rhythm is indicated in the text by a sign "dash"): "While you're walking - you're on the road. As long as you think, you act. As long as you act, people need you, God, you need yourself. This is what I ask for in my daily prayers - needs. Thank you for this every night. Thank you for the day, with my work, my plans, my money" (Dochynets, 2016, p. 329). Short syntactic constructions and repetition of key words (epanaphora) create a lively rhythm of the story, which sets the recipient to a conversation with a wise old man and should motivate him to be active. 


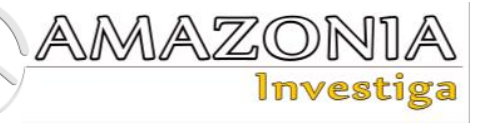

In descriptions of nature, $M$. Dochynets actively uses visual, gustatory, auditory, olfactory accents (verbal-sound markers), which activate the potential of figurative thinking of the recipient. For example, in the novel "Centenarian", the writer creates the rhythm of the forest with the help of 1) color and sound accents: "And the forest, gathering leaves, thickened and blackened more and more. In the green thicket, a new dark life was now being born there. Something crackled, fluttered, groaned, forged. And at night he sighed and groaned like a weary man. <...> Frogs shouted loudly ... The stream boiled, shifting stones. <...> Some bird cried incessantly like a jinxed child. The rock shook calmly, as if someone was pounding inside it ..." (Dochynets, 2013a, p. 31-32); 2) sound-imitating reproduction of birds singing: "Blue-headed finch whistles a silver song in good weather: "pink... pink ... fit ... fit ...", or: "ryu-pin-pin-ryu". Then wait for the rain" (p. 89). Artistically reproducing the rhythm of nature, the writer uses the expressive potential of alliteration to enhance the intonational expressiveness of the work.

An integral part of the film poetics of the prose by $M$. Dochynets is a shot and perspective that represent the original philosophy of the main characters. Centenarian, Highlander, WellDigger, Maftei are representatives of the autochthonous Ukrainian sub-ethnic group of mountaineers, endowed with a unique worldview and worldview of the inhabitants of the Carpathians. For example, in the novel "Highlander" with the help of the shots' size (close-up) the writer emphasizes the conservatism of the protagonist, which is manifested in the imitation of folk and family traditions. Until the death of his wife and the partial destruction of the house by the elements, the character lived a measured life of a goose from the top, like previous members of his family. After the tragedy, Highlander is shocked not only by the loss of a loved one, but also by the realization that the cause of the event was River, whom he perceived as a living being and considered a friend. Important for understanding the concept of the character is the visualization of his interaction with the environment, and, most importantly, the River. The writer actively uses the possibilities of the cinematic shot, to characterize the protagonist, to explain the motivation of his actions.

Using a panoramic shot in the episode of Highlander's inspection of his yard and shore after returning from the hospital, the author provides the recipient with information about the place of action of the work and reveals the conflict "man-nature”. For the protagonist, this is an important moment of identifying himself as a defender of the "family nest". Examining the space around, the character understands the decision of the ancestors to settle in this place and agrees. "Not far from the dusty road, from the interested human eyes, under the crowned growth of the rock, surrounded by the belt of the River, dreamily lay their ancestral space. <...> Here, in a warm hollow, the grass ripened earlier, the bush bloomed more abundantly, and the pine resin smelled sharper and breathed easier, because the air was filled with a tickling haze of waterfalls" - the narrator notes (Dochynets, $2013 \mathrm{~b}$, p. 15). In this fragment, the camera is at the level of the protagonist's eyes: "The old man looked away from the fresh abyss, turned his look through the living rows of trees that held the shore with strong paws of roots - alder, larch, ash, spruce, maple. Green wall in three rows" (p. 15). The solemnity of the decision to become the guardian of the space, which is the bearer of ancestral memory, is emphasized by the illusion of reducing the distance between the character and the elements of the landscape, between the character and the viewer.

Having chosen the path of struggle with River, Highlander actualizes the knowledge and skills he received from the representatives of his family. The narrator repeatedly compares the appearance, character and abilities of the character with other members of the family and concludes that he is similar to his grandfather and uncle. For example, the narrator notes that the protagonist learned to cut down trees at a young age, watching his grandfather Mykula. Despite his respectable age, he can withstand significant physical exertion: mowing the grass, digging, chopping trees, carrying stones. The text of the work repeatedly contains descriptions of the character's active work, for the visualization of which the first close-up ("The old man shone with a wet face like the blade of his ax" (Dochynets, 2013b, p. 105)), the second middle plan ("The old man dragged them to the river. So horses in the woods pull cut whips. He pulled intermittently, resting after each step" (p. 62)), and the general shot ("The stars of heaven were still dripping branches in the dew of the earth, and the man was already standing barefoot under a tree, resting his chest and forehead on the trunk" (p. 101)).

For the interpretation of the inner world of M. Dochynets' characters, a close-up is crucial, which provides the recipient with important information about the appearance of Andriy Voron, Highlander, Well-Digger and Maftei. All 
the protagonists of a writer of respectable age, which the narrator emphasizes with the help of gerontological markers - long gray hair, beard, etc. These eloquent details build the image of a sage-hermit, a healer, a folk philosopher: "I remembered that grandfather - silent, with a wise long look, bearded, in a rough woolen sweater. Something like Hemingway, but not bookish. With some Greek restrained, unspoken essence" (Dochynets, 2014, p. 6). The image of a wise old man subconsciously evokes a sense of respect, trust in the proclaimed truths, a desire to follow the life philosophy of the character - to find his "nature work" and with its help to serve God, the Fatherland, people.

\section{Conclusions}

Modern Ukrainian novel is actively developing in genre, style, problem-thematic and other areas. The intermediate vector of modernization of writers' prose involves the involvement of various inter-artistic means. The film poetics of the modern Ukrainian novel is characterized by a variety of effectively used artistic means and techniques. In the novels "Centenarian", "Svitovan", "Highlander", "Well-Digger", "Maftei" by M. Dochynets, the means of film poetics perform intonation-expressive, problemthematic, plot-compositional and characterological functions important for the author's idea. With the help of montage, film frame, shot, rhythm, perspective, etc. the writer recreates the inner world of the characters, reveals the specifics of their philosophy of life, artistically comprehends ethnopsychological features (conservatism, love of nature, aesthetics, persistence, etc.), expresses thematic corpus of works narratological, spatiotemporal specifics of novels.

Building a story in the form of a memoir, the modern Ukrainian novelist M. Dochynets creates the effect of visualization, which brings his literary texts closer to cinematic samples. The narrative style chosen by the writer conditionally divides the whole literary text into separate fragments, which are combined in the context of the whole work. Actively using the possibilities of parallel retrospective editing, the writer artistically recreates the inner world of the characters at different ages: childhood, adolescence, youth of the protagonist, who gradually approaches adulthood, being in a process of constant self-improvement and finding his place in the world. A wise old man rethinks his past through the prism of life experience. In the writer's prose, the combination and alternation of the character's memories with his thoughts and impressions within the chronological-linear narrative is a factor in the rhythm of the action, as well as an important means of reproducing the inner world of the protagonists.

In the prose by M. Dochynets the accentuation of attention at a certain moment of the plot, the expression of the author's attitude to the depicted, the emotional influence on the recipient is achieved with the help of 1) detail, first closeup, middle, second middle, general, panoramic plans; 2) representations of characters from different positions, illusions of reducing the distance between the character, certain elements of his environment and the viewer, showing the character from the bottom up, and etc.

The use of the cinemapoetics elements in the M. Dochynets' literary works reveals the high artistic and aesthetic orientations of the artist, his erudition, artistic taste and testify to the demand for film poetics in modern Ukrainian novels.

\section{Bibliographic references}

Braiko, O. (2017). Cinematographic visualization of space in small prose of Eugene Gutsal. World and Time: Scientifictheoretical Journal, 1, 36-46 [in Ukrainian]. http://www.dspace.nbuv.gov.ua/handle/1234 $56789 / 158826$.

Bulbachynska, O. (2019). Reception of montage in the formation of artistic meanings of the novel "Private Life of a Phenomenon" by E. Gutsal. Bulletin of Zhytomyr State University named after Ivan Franko. Philological sciences, 3(91), 7-15 [in Ukrainian].

https://doi.org/10.35433/philology.3(91).201 9.7-15

Camus, A. (1990). Rebellious Man. Philosophy. Politics. Art. Moscow: Politizdat. Retrieved from:

https://www.imwerden.de/pdf/camus_buntu yushhy_chelovek_1990.pdf [in Russian]

Chicherin, A. (1980). The rhythm of the image. Stylistic problems. Moscow: Soviet writer. [in Russian]

Dochynets, M. (2013a). Centenarian. Confession on the Pass of the Spirit. Mukachevo: Carpathian connection. [in Ukrainian]

Dochynets, M. (2013b). Highlander. Waters of Our Lord's Riverbeds. Mukachevo: Carpathian connection. [in Ukrainian]

Dochynets, M. (2014). Svitovan. Studies under the Tent of the Skies. Mukachevo: Carpathian connection. [in Ukrainian] 


\section{AMAZONDA \\ 1ึvestiำ}

Dochynets, M. (2016). Well-Digger. Diary of the Richest Resident of Mukachevo Dominion. Mukachevo: Carpathian connection. [in Ukrainian]

Dochynets, M. (2013c). Word Lamp. Mukachevo: Carpathian connection. [in Ukrainian]

Dotsenko, N. (2015). The prose by Patrick Modiano (principles of intermediality). Kyiv. [in Ukrainian]

Ezenstein, S. (1968). Cinema and Literature (On the imagery). Literature questions, 1, 91-112. [in Russian]. https://www.voplit.ru/author/ejzenshtejnsergej/

Filatov, A. (2012). Cinema vs literature: Ukrainian writers-cinematographers.

Bookstore "Ye" Retrieved from: http://litakcent.com/2012/09/26/kino-vsliteratura-ukrajinski-pysmennykykinematohrafisty/ [in Ukrainian]

Kravchenko, N., Davydova, T., \& Goltsova, M. (2020). A Comparative Study of Fairy Tale and Rap Narratives: Spaces Specificity. Journal of History Culture and Art Research,
9(3), 155-167. [in Ukrainian] https://pdfs.semanticscholar.org/9c8d/45004 0cef0ef851fca0a9a4f531b148f68af.pdf

Lotman, Yu. (1992). Articles on semiotics and typology of culture/ Selected articles: In 3 volumes. Tallinn: Alexandra. [in Russian] http://yanko.lib.ru/books/cultur/lotmanselection.htm

Lotman, Yu. (1998). About art. St. Petersburg: Art - SPB [in Russian]. Retrieved from: https://www.phantastike.com/semiotics/ob_i skusstve/djvu/

Romm, M. (1964). Conversations about cinema. Moscow: Art. [in Russian]. https://www.livelib.ru/book/1001268608besedy-o-kinorezhissure-mihail-romm

Sartre, J.P. (1948). Existentialism is a humanism. Moscow: Politizdat. Retrieved from: http://www.psylib.org.ua/books/sartr01/inde x.htm. [in Russian]

Tarkovsky, A. (1979). About the film image. The art of cinema, 3, 80-93. Retrieved from: https://yadi.sk/i/YGkgPkdv34FD5k [in Russian] 